DOI 10.37882/2223-2982.2021.03.05

\title{
ЛИНГВИСТИЧЕСКАЯ НЕВЕЖЛИВОСТЬ СРЕДИ НОСИТЕЛЕЙ РУССКОГО ЯЗЫКА В АНОНИМНОМ ИНТЕРНЕТ-ОБЩЕНИИ
}

\section{LINGUISTIC IMPOLITENESS AMONG RUSSIAN SPEAKERS IN ANONYMOUS INTERNET COMMUNICATION}

E. Baev

Summary: This article is devoted to the study of impolite communication in conditions of complete anonymity. The types of anonymity that are encountered in communications in the Internet environment are described, and the criteria for identifying the type of anonymity that are of interest in connection with the study of impoliteness are formulated. The main patterns of forming face-threatning acts in conditions of anonymity are outlined. Study also describes what speech strategies of impoliteness are based on the anonymity of communication.

Keywords: linguistic (im)politeness, speech aggression, the factor of anonymity in communication, anonymous communication, facethreatning acts.

\author{
Баев Евгений Владимирович \\ Аспирант, Московский городской \\ педагогический университет \\ BaevEV@mgpu.ru
}

Аннотация: Данное исследование посвящено изучению невежливости в коммуникациях в условиях полной анонимности. Рассматриваются типы анонимности, встречающиеся в коммуникациях в Интернет-среде, и форулируются критерии для выделения того типа анонимности, который представляет интерес в связи с изучением невежливости. Обозначаются основные закономерности того, как коммуниканты создают ликоугрожающие акты в условиях анонимности, и какие речевые стратегии невежливости опираются на сам факт анонимности коммуникации.

Ключевые слова: лингвистическая (не)вежливость, речевая агрессия, фактор анонимности в коммуникации, анонимное общение, ликоугрожающие акты.

\section{BBEAEHИE}

$\mathrm{B}$ статье рассматриваются принципы проявления лингвистической невежливости в анонимном Интернет-общении. В качестве теоретического основания работы используются положения о том, что: спонтанное письменное общение в сети Интернет является разговорной речью (письменной), как это продемонстрировано Литневской Е.И. [Литневская, с. 74]; лингвистическая (не)вежливость - это набор коммуникативных стратегий, которые доказали свою целесообразность [Thomas, c. 179], одним из подходов к описанию которых является т.н. «face-based politeness» - идея вежливости как лингвистической сущности, описанной в социолингвистических терминах «лица», «ликоугрожающих актов» - концепция, заложенная фундаментальным трудом Браун П. и Левинсона С., являющаяся наиболее известной и изученной из всех [Culperer, c. 6-7]; наконец, наше собственное убеждение, что в отечественной лингвистике понятие лингвистической невежливости в определенной степени сливается с понятием речевой агрессии - «целенаправленного коммуникативного действия, ориентированного на то, чтобы вызывать негативное эмоционально-психологическое состояние у объекта речевого воздействия» [Седов, с. 88].

Актуальность настоящего исследования обусловлена тем вниманием, что привлекает к себе изучение лингвистической (не)вежливости последние два десятилетия - после программной статьи Дж. Калперера [Леонтьев, с. 134]. Причем целый ряд исследований отечественных лингвистов только за последние пять лет частично или полностью опирается либо на классическую теории вежливости Браун-Левинсона (Власян Г.Р., Павлова А.В., Голощапова М.В., Зотенина Т.С., Фенина В.В. и пр.), либо на ее постмодернистские интерпретации (Габдрафикова Т.Ш., Горина О.Г., Храброва В.Е.). Однако указанные выше и многие другие авторы проводят свой анализ на иноязычном языковом материале (в первую очередь английском и немецком), что, вероятно, объясняется статусом лингвистической (не)вежливости как относительно новой области лингвистических исследований и практически полным отсутствием переведенной литературы, закладывающей основы данной области исследований.

Невежливость и речевая агрессия в Интернет-общении также становится частым предметом исследования в последние годы. Приведем некоторые примеры. Конкретные формы речевой агрессии, сформировавшиеся в среде Интернет изучались на примере «троллинга» и «флейминга» [Воронцова, 2016]. Особенности реализации «троллинга» изучались на материале французского языка [Абдуллина, Артамонова, 2017]. Троллинг также изучался с точки зрения несоответствия этико-правовым нормам [Курьянович, 2018]. Лексико-семантический и грамматический уровни реализации речевой агрессии исследовались в т.ч. и на русскоязычном языковом материале [Смирнов, 2017]. 
Эти и многие другие исследования проводились на материалах общения в Интернет-среде, где на большинстве площадок пользователи сохраняют ту или иную степень анонимности. Однако не всякая степень анонимности представляет интерес для нас. Кроме того, сам фактор анонимности ранее не подвергался серьезному анализу с позиции теории вежливости, базированной на понятии «лица».

\section{ВИАЫ АНОНИМНОСТИ В КОММУНИКАШИИ}

Мы считаем, что только один тип анонимности представляет интерес для исследования лингвистической (не)вежливости с позиций классической теории вежливости Браун-Левинсона или ее пост-модернистской интерпретации. И классическая теория, и ее более поздняя версия в своей основе имеют понятие двух социальных лиц: позитивного лица («роsitive face»), конструкта, описывающего потребность коммуниканта в уважении, признании, одобрении, и негативного лица («negative face»), конструкта, описывающего стремление коммуниканта сохранить свою самостоятельность [Brown, p. 62].

Постмодернистская интерпретация теории, критикуя фокус классической теории на изолированных и неаутентичных речевых фрагментах, все еще базируется на понятии социального лица, закладывая его в новое ключевое понятие «relational work» [Locher, p. 11-13]. Это понятие описывает работу коммуникантов над их межличностными отношениями и включает в себя стремление сохранить коммуникантом свое социальное лицо, хотя данный подход и смещает понимание социального лица с интерпретации Браун-Левинсона обратно на первоисточник термина (т.е. работы Э. Гоффмана) [Locher M., Miriam A., p. 518].

Таким образом, несмотря на безусловную необходимость и большой потенциал описания принципов «relational work» в среде Интернет, обыкновенное общение в чатах/ мессенджерах/ на форумах и т.п., где анонимность обеспечивается скрытием истинной личности под «никнеймом» не является предметом настоящего исследования. Несмотря на определенные особенности поведения, которые могут иметь место вследствие чувства защищенности адресантов, у них все еще есть регулярное социальное лицо (т.е. собеседник может вычленить адресантов в потоке общения по его никнейму, аватарке и т.п.), и потому коммуниканты не избавлены полностью от последствий использования ликоугрожающих актов.

Под общением в условиях «истинной анонимности» мы будем понимать такое общение, при котором выполняется хотя бы одно из следующих условий:

- коммуниканты не могут быть уверены, что каждый последующий речевой акт произведен новым коммуникантом (или наоборот, что все речевые акты произведены одним и тем же коммуникантом), а количество вовлеченных коммуникантов остается неизвестным всем участникам общения;

- последствия от используемых стратегий и тактик речевого общения обнуляются (либо регулярно в силу независящих от пользователей обстоятельств, либо по желанию пользователя, либо же репутационные издержки в принципе не могут быть приписаны даже временному социальному лицу).

\section{НАБАЮ ААЕМЫЕ ОСОБЕННОСТИ НЕВЕУКАИВОСТИ В АНОНИМНОМ ОБШЕНИИ}

Материал, подпадающий под «истинно анонимное» общение редко становится предметом изучения исследователей. Так, с позиции изучения стратегий и тактик анонимное письменное общение изучалось на материале немецкого языка [Габдрафикова], и предметом исследования служили коммуникативные акты, использованные пользователями немецкой имиджборды «Краутчан» («Krautchan») - платформы, обладающей предложенными нами признаками общения в условиях истинной анонимности. Пользователи данной коммуникативной платформы общаются в условиях исходной анонимности (пользователи не идентифицируются ни числовыми, ни семантическими «именами», при желании могут отвечать сами себе, имитируя диалог, количество участвующих в каждом обсуждении (треде) не фиксируется и неизвестно участникам, любые понесенные репутационные «потери» участников не фиксируются и обнуляются). В русскоязычной среде аналогами являются имиджборды «Двач», «Доброчан», «Тиреч» и пр.

Исследование Габдрафиковой, однако, изучало неаутентичную невежливость, чьей целью является демонстрация солидарности с другими пользователями [Габдрафикова, с. 496]. Данное явление представляет собой речевую стратегию, допустимую между коммуникантами, находящимися в дружеских близких отношениях, называемую обычно «речевым подтруниванием («friendly banter») [Леонтьев, с. 120]. Данное явление следует отличать как от прямой, так и от непрямой/ косвенной речевой агрессии, которую выделяет Седов К.Ф., и чья «негативная иллокуция не вытекает из суммарного значения входящих в высказывание компонентов» [Седов, с. 89], о которой ведется речь в настоящем исследовании.

Мы подвергли анализу 3000 постов (около 13 дискуссионных тем, созданных в течении месяца) информационно-коммуникативной площадки «Двач» (www.2ch. hk) на предмет проявления в них лингвистической невежливости, целью которой является нападение на социальное лицо адресата. Наш первостепенный интерес представляют следующие вопросы:

- как реализуются ликоугрожающие акты в услови- 
ях, когда социальное лицо адресанта непрозрачно для адресата?

- какие особенности ликоугрожающих актов в виртуальной Интернет-среде можно отнести на счет влияния анонимности, а какие - на счет влияния дискурса коммуникативной площадки, на которой ведется общение?

Первой отмечаемой особенностью является связь с групповой идентичностью, или прокси-характер многих ликоугрожающих актов - они направлены в первую очередь на определенную социальную/ этническую/ идеологическую группы или приверженцев определенного мнения. Наименования этих групп «из уст» адресатов обычно выполняют двойственную функцию: обозначение круга социальных лиц, на которые адресат желает произвести нападение, и, собственно, инвективизация данного именования. Когда социальные лица друг друга коммуникантам неизвестны, невежливость адресуется т.н. «коллективному социальному лицу», сочетающему идеологические или просто стереотипно присущие группе лиц взгляды.

Это хорошо видно на примерах обсуждений, затрагивающих политические и культурные конфликты между русскими и украинцами. В ход идет копрологическая и зоологическая инвективизация, в основе которой лежит языковая игра: «срусские», «Сруссия», «Пукраина», «Хрюкраина», «Пахомия». Однако данный паттерн - использование языковой игры в наименованиях социальных групп с двойственной прагматической функцией - наблюдается не только при именовании этнических групп, например: «хатаскрайники» (те, кто ведет себя сообразно принципу «моя хата с краю»), «безумная сосака» (обозначение аудитории сайта 2ch.hk - языковая игра, созданная на основании некогда использовавшегося домена 2ch.so - «сосач», «сосака»), «натрахи» (презрительное обозначение русских девушек за границей, актуализирующее стереотип об их распутном поведении).

Разумеется, анонимность не могла не сказаться на частоте употребления инвективов. Помимо специфических инвективов, нацеленных на групповую идентичность, широко употребляются обычные инвективы (сексуальные, скатологические, зоологические и пр.).

Не во всех инвективах, образуемых с помощью языковой игры, преобладает фатическая семантика. Некоторые из них успешно совмещают ее с передачей определенной информации - с обвинениями или информации агитационного характера: «пересидент» (про президента - намек на то, что он «пересидел» президентский срок и «пересиживает» эпидемию в бункере), «неконцлагерь» (про Россию - языковая игра строится на нарочитом отвержении термина «концлагерь» в отношении страны. В контексте, где этот термин еще никто не упоминал, дан- ный речевой акт работает именно на актуализацию семантики «концлагеря»), «рабские вымираты» (также про Россию, языковая игра, строящаяся на названии иной страны - по мнению адресанта более богатых и успешных Арабских эмиратов). Мы считаем, что стремление совместить в ликоугрожающем акте инвективную и информативную роль является еще одним проявлением фактора анонимности в коммуникации - это является еще одним способом атаки на негативное лицо коммуниканта посредством атаки на негативное лицо групповой идентичности, к которой принадлежит коммуникант.

Еще одной особенностью невежливого анонимного Интернет-общения является использование коммуникантами креолизованных текстов. Креолизованные тексты обычно представляют собой языковую игру, формирующую инвективную семантику, но с помощью поддерживающих семантику иконических средств. Например, в креолизованных текстах часто используется прием псевдо-цитирования, основывающийся на искажении слов адресанта или даже их точного цитирования, сопровождающегося иконическим средством, которое должно олицетворять адресанта. Как правило, иконическое средство изображает адресанта в плохом свете (некрасивый, страдающий каким-либо заболеванием, член маргинализованной социальной группы). Таким образом адресуется факт анонимности общения (адресант чувствует себя вправе приписывать собеседнику любые внешние недостатки или причислять его к любой социальной группе, к которой считает верным, так как у адресата нет возможности прямо опровергнуть данное оскорбление). Характерно, что групповая идентичность в качестве основы для атаки на негативное лицо коммуниканта используется и здесь.

Анонимность общения адресуется коммуникантами в т.ч. в риторических вопросах с инвективной семантикой и в предикативных. Рассмотрим следующий пример.

Под новостью о возвращении сотрудника ФБК из армии один из пользователей интересуется, почему информационный шум поднимается из-за одного человека, а не из-за всех тех, кого забирают в армию на регулярной основе («сколько пачанов за год так в армию забирают?»). Ему отвечают языковой шуткой, основанной на пресуппозиции, утверждающей, что сотрудники ФБК в целом (или обсуждаемый в новости молодой человек в частности) является лицами нетрадиционной сексуальной ориентации (с употреблением инвектива - «по закону пидарасов не должны призывать»). Что, в свою очередь, провоцирует создание другой шутки, атакующей уже негативное лицо коммуниканта, первым употребившего инвективу - шутки, вряд ли возможной в условиях неанонимного общения: «поэтому батю твоего не призвали?». Этот прием также базируется на анонимности общения - адресант не способен прямо опровер- 
гнуть пресуппозицию, на которой строится шутка.

Причем дело даже не в том, что подобный ликоугрожающий акт в условиях более традиционного общения лицом к лицу или при свидетелях наносит значительный урон не только негативному лицу адресата, но и позитивному лицу адресанта. Эффективность риторического вопроса с инвективной семантикой определяется именно анонимностью общения, где ответ «вообще-то мой отец служил в армии» не будет звучать так же убедительно, как в реальной жизни, где эти слова будут подкреплены осознанием коммуникантами репутационных издержек, которые может понести каждый из коммуникантов в случае лжи.

Как нетрудно заметить по приведенным примерам, лингвистическая невежливость может и активно используется в виртуальной среде даже при полной анонимности и невозможности эффективно вычленять в коммуникативном потоке социальные лица собеседников.

\section{ВывО $\triangle \mathrm{b}$}

В условиях, когда социальное лицо адресанта непрозрачно для адресата и регулярно «обнуляется», т.е. все последствия «relational work» стираются после завершения коммуникации, коммуниканты обнаруживают тенденцию обращаться к коллективному социальному лицу других коммуникантов, к их групповой идентичности, выраженной в определенной идеологической позиции, мнении по определенному вопросу, или, в более простых случаях, лексемах, прямо обозначающих групповую идентичность (этнонимах или авторских лексемах, образованных с помощью языковой игры).

Ликоугрожающие акты сосредотачиваются на сакральных для данной группы объектах и абстрактных понятиях. Поскольку в условиях истинной анонимности социальные лица коммуникантов не сохраняют понесенный урон, инвективы, сосредоточенные на групповой идентичности и доказавшие свою эффективности, используются часто, повторяются, и становятся предметом языковой игры для их реакутализации. Также из-за этого инвективы ощутимо редко имеют только фатическую роль - хотя в общении «лицом к лицу» такая ситуация совсем нередка. В условиях анонимного общения инвективы обнаруживают стремление к передаче сложных смыслов, сохраняют и транслируют аллюзии и отсылки к актуальным инфоповодам и мнениям.

Анонимность коммуникации находит свое отражение в некоторых стратегиях невежливости - в приеме псевдо-цитирования с искажением слов коммуниканта или их утрированием, в приеме цитирования с иконическим средством, играющим роль проассоциированного с личностью коммуниканта инвектива, в приеме использования пресуппозиции для навязывания жертве определенной групповой идентичности.

\section{ЛИТЕРАТУРА}

1. Воронцова Т.А. Троллинг и флейминг: речевая агрессия в интернет-коммуникации // Вестник Удмуртского университета. Серия «История и филология». 2016. №2. URL: https://cyberleninka.ru/article/n/trolling-i-fleyming-rechevaya-agressiya-v-internet-kommunikatsii (дата обращения: 21.01.2021).

2. Литневская Е.И. Письменная разговорная речь: миф или реальность? // Вестник Московского университета. Серия 9. Филология. 2011. №5. URL: https://cyberleninka.ru/article/n/pismennaya-razgovornaya-rech-mif-ili-realnost (дата обращения: 21.01.2021).

3. Габдрафикова Т.Ш. Стратегии неаутентичной речевой агрессии в виртуальной среде // Филологические науки. Вопросы теории и практики. 2018. №12-3 (90). URL: https://cyberleninka.ru/article/n/strategii-neautentichnoy-rechevoy-agressii-v-virtualnoy-srede (дата обращения: 21.01.2021).

4. Леонтьев В.В. Речевое подтрунивание в русской и английской лингвокультурах // Жанры речи. 2018. № 2 (18). С. 119-126.

5. Леонтьев В.В. «Темная сторона» вежливости: историко-прагматический анализ номинаций ее субъектов в русской лингвокультуре // Мир лингвистики и коммуникации: электронный научный журнал. - 2018, № 4. - С. 132-162.

6. Седов Константин Федорович Агрессия и манипуляция в повседневной коммуникации // Юрислингвистика. 2005. №6. URL: https://cyberleninka.ru/ article/n/agressiya-i-manipulyatsiya-v-povsednevnoy-kommunikatsii (дата обращения: 21.01.2021).

7. Bernal M. Do Insults Always Insult? Genuine Impoliteness versus Non-genuine Impoliteness in Colloquial Spanish // Pragmatics. Amsterdam: John Benjamins Publishing Company, 2008. P. 775-802.

8. Brown P., Levinson S. (1987). Politeness: Some universals in language usage. Cambridge: Cambridge University Press. 345 p.

9. Culpeper J. Politeness and impoliteness. // Karin Aijmer and Gisle Andersen (eds.) Sociopragmatics, Volume 5 of Handbooks of Pragmatics edited by Wolfram Bublitz, Andreas H. Jucker and Klaus P. Schneider. Berlin: Mouton de Gruyter, 391-436.

10. Locher M., Miriam A. Relational work, politeness and identity construction. // Handbooks of applied linguistics: communication competence, language and communication problems, practical solutions. Vol. 2, Handbook of interpersonal communication, pp. 509-540.

11. Locher M., R. Watts. Politeness Theory and Relational Work // Journal of Politeness Research, 2005. Vol. 1, pp. 9-33.

12. Thomas J. Meaning in Interaction: An Introduction to Pragmatics (Learning about Language). London and New York: Longman. // Open Journal of Modern Linguistics. Vol.5, No.4. 